Open Access

\title{
Bee venom ameliorates lipopolysaccharide- induced memory loss by preventing NF-kappaB pathway
}

Sun Mi Gu${ }^{1 \dagger}$, Mi Hee Park ${ }^{1 \dagger}$, Chul Ju Hwang ${ }^{1}$, Ho Sueb Song ${ }^{2}$, Ung Soo Lee ${ }^{3}$, Sang Bae Han ${ }^{1}$, Ki Wan Oh', Young Wan $\mathrm{Ham}^{4}$, Min Jong Song ${ }^{5}$, Dong Ju Son ${ }^{1 *}$ and Jin Tae Hong ${ }^{1 *}$

\begin{abstract}
Background: Accumulation of beta-amyloid and neuroinflammation trigger Alzheimer's disease. We previously found that lipopolysaccharide (LPS) caused neuroinflammation with concomitant accumulation of beta-amyloid peptides leading to memory loss. A variety of anti-inflammatory compounds inhibiting nuclear factor kappaB (NF-KB) activation have showed efficacy to hinder neuroinflammation and amyloidogenesis. We also found that bee venom (BV) inhibits NF-KB.

Methods: A mouse model of LPS-induced memory loss used administration of BV ( 0.8 and $1.6 \mu \mathrm{g} / \mathrm{kg} / \mathrm{day}$, i.p.) to ICR mice for 7 days before injection of LPS (2.5 mg/kg/day, i.p.). Memory loss was assessed using a Morris water maze test and passive avoidance test. For in vitro study, we treated BV $(0.5,1$, and $2 \mu \mathrm{g} / \mathrm{mL})$ to astrocytes and microglial BV-2 cells with LPS (1 $\mu \mathrm{g} / \mathrm{mL})$.

Results: We found that BV inhibited LPS-induced memory loss determined by behavioral tests as well as cell death. BV also inhibited LPS-induced increases in the level of beta-amyloid (A $\beta$ ), $\beta$-and $\gamma$-secretases activities, NF-KB and its DNA-binding activity and expression of APP, and BACE1 and neuroinflammation proteins (COX-2, iNOS, GFAP and IBA-1) in the brain and cultured cells. In addition, pull-down assay and molecular modeling showed that BV binds to NF-KB.
\end{abstract}

Conclusions: BV attenuates LPS-induced amyloidogenesis, neuroinflammation, and therefore memory loss via inhibiting NF-KB signaling pathway. Thus, BV could be useful for treatment of Alzheimer's disease.

Keywords: Alzheimer's disease, Beta-amyloid, Bee venom, Nuclear factor kappaB, Lipopolysaccharide, Neuroinflammation

\section{Introduction}

Alzheimer's disease (AD) is the most common neurodegenerative disease due to loss of neurons in the brain. Typical early symptoms of AD patients are losing their ability to learn new information and then loss of both declarative and non-declarative memory [1]. $\mathrm{AD}$ is generally known to be correlated with accumulation of beta-amyloid $(A \beta)$ peptides which is produced from amyloid precursor protein (APP) $[2,3]$. APP is decomposed

\footnotetext{
* Correspondence: sondj1@chungbuk.ac.kr; jinthong@chungbuk.ac.kr ${ }^{\dagger}$ Equal contributors

College of Pharmacy and Medical Research Center, Chungbuk National University, 194-31 Osongsaemgmyeong 1-ro, Osong-eup, Heungdeok-gu, Cheongju, Chungbuk 361-951, Republic of Korea

Full list of author information is available at the end of the article
}

into soluble amyloid precursor protein beta (sAPP $\beta)$ and carboxy-terminal 99 amino acid (C99) protein by $\beta$-site APP cleaving enzyme ( $\beta$-secretase; BACE1), and then $\gamma$-secretase produces $A \beta$ and amyloid intracellular domain (ACID) from C99 [4]. AD patients have showed a high level of $A \beta$ output and aggregative $A \beta$ [5].

Lipopolysaccharide (LPS) can trigger neuroinflammation and influence amyloidogenesis in neuronal cells. LPS activates inflammatory cells such as astrocytes and microglia cells in the brain, thus enhancing neuroinflammation [6-9]. LPS also induces accumulation of $A \beta$ through increased cleavage of APP by increasing BACE1 and $\gamma$-secretase activation $[9,10]$. Nuclear factor kappaB (NF-KB) can be activated by LPS, and then induces 
several inflammatory genes such as tumor necrosis factor-a (TNF- $\alpha$ interleukins (IL-1 $\beta$, IL-6, and IL-18), inducible nitric oxide synthase (iNOS), and cyclooxygenase-2 (COX-2) [11]. NF-kB also induces decomposition of APP by activating BACE1. BACE1 promoter activity and BACE1 transcription are increased by activating NF- $\mathrm{kB}$ because the BACE1 promoter has a NF-kB-binding site $[12,13]$. Therefore, inhibiting NF- $\mathrm{kB}$ pathways could interrupt generation of $A \beta$ as well as neuroinflammation [14]. A variety of anti-inflammatory compounds inhibiting NF- $\mathrm{kB}$ activation, such as (-)-epigallocatechin-3gallate (EGCG), thiacremonone, and N-adamantyl-4methylthiazol-2-amine (KHG26693), have showed efficacy to hinder neuroinflammation and amyloidogenesis, and thus reduce memory loss [14-17].

Bee venom (BV) has been used as a traditional cure in oriental countries [18]. Various diseases, such as arthritis, rheumatism, and cancer have been treated by BV [19]. BV consists of various active components, for example: peptides (e.g., melittin, apamin, adolapin, and the mast cell degranulating peptide; MCD), enzymes (e.g., phospholipase $\mathrm{A}_{2} ; \mathrm{PLA}_{2}$, hyaluronidase, glucosidase), and biogenic amines (e.g., histamines, dopamine, norepinephrine) [19]. Several research groups have proved the anti-inflammatory effect of BV in several disease models such as a mouse model of Parkinson's disease, Freund's adjuvant-induced rheumatoid arthritis (RA) model, and cholecystokinin octapeptide-induced acute pancreatitis rat model [20-22]. BV and its major component melittin inhibited LPS and TNF- $\alpha$-induced NF- $\mathrm{kB}$ activation by interrupting p50 translocation through interaction with sulfhydryl residue of p50 or IKB kinases $(\mathrm{IKK} \alpha$ and IKK $\beta)$ [23, 24]. Our study also showed that BV prevented LPS-induced nitric oxide (NO) and prostaglandin $\mathrm{E}_{2}\left(\mathrm{PGE}_{2}\right)$ production through inactivation of NF-kB in RAW 264.7 cells [25]. In this study, we investigated whether BV inhibits neuroinflammation response and amyloidogenesis through inactivation of NF- $\mathrm{kB}$ in vitro and in vivo, and thus reduces memory lose by LPS.

\section{Materials and methods Materials}

BV was purchased from You-Miel Bee Venom Ltd. (Hwasoon, Jeonnam, Korea). The composition of the BV was as follows: $45-50 \%$ melittin, $2.5-3 \%$ mast cell degranulating peptide, $12 \%$ phospholipase A2, $1 \%$ lysophospholipase A, 1-1.5\% histidine, 4-5 \% 6-pentyl a-pyrone lipids, $0.5 \%$ secarpin, $0.1 \%$ tertiapin, $0.1 \%$ procamine, $1.5-2 \%$ hyaluronidase, $2-3 \%$ amine, $4-5 \%$ carbohydrate, and 19-27\% of others, including protease inhibitor, glucosidase, invertase, acid phosphomonoesterase, dopamine, norepinephrine, and unknown amino acids, with $99.5 \%$ purity. Melittin was purchased from Sigma-Aldrich (St. Louis, MO).

\section{Animals and treatments}

Seven- to eight-week male imprinting control region (ICR) mice (Daehan Biolink, Chungcheongbuk-do, Korea) were maintained and handled in accordance with the humane animal care and use guidelines of the Korean FDA. All experiments were approved and carried out according to the Guidelines for the Care and Use of Animals [Animal Care Committee of Chungbuk National University, Korea (CBNUA-436-12-02)]. All efforts were made to minimize animal suffering, to reduce the number of animals used. All mice were housed in a room with automatic control of temperature $\left(21 \sim 25{ }^{\circ} \mathrm{C}\right)$, relative humidity (45-65\%), and light-dark (12-12 h) cycles. To induce neuroinflammatory cognitive impairment model, LPS $(2.5 \mathrm{mg} / \mathrm{kg})$ was administrated intraperitoneally [26]. The LPS (serotype O55:B5, Sigma, St. Louis, MO. USA, final concentration of $1 \mathrm{mg} / \mathrm{mL}$ ) was dissolved, and aliquots in distilled water (DW) were stored at $-20{ }^{\circ} \mathrm{C}$ until use. The BV (final concentration of $1 \mathrm{mg} / \mathrm{mL}$ ) was dissolved in DW, and aliquots were stored at $-20{ }^{\circ} \mathrm{C}$ until use. These are the following four groups: (I) saline + saline group (control); (II) saline + LPS group (LPS); (III) BV $(0.8 \mu \mathrm{g} / \mathrm{kg})+$ LPS group (BV 0.8); and (IV) BV $(1.6 \mu \mathrm{g} / \mathrm{kg})+$ LPS group (BV 1.6), and each group was assigned to eight mice. First, intraperitoneal (i.p.) injection $(0.8 \mu \mathrm{g} / \mathrm{kg}, 1.6 \mu \mathrm{g} / \mathrm{kg})$ of BV and i.p. injection $(2.5 \mathrm{mg} / \mathrm{kg})$ of LPS or control (saline) was administered after $30 \mathrm{~min}$. The doses of BV were the same with the previous study [23]. This step was performed daily for seven days. And then, the behavioral tests of learning and memory capacity were assessed using two separate tests (water maze and passive avoidance test). After training once beforehand (day 0), the test was performed in the date of the first, third, and seventh day (Fig. 1a).

\section{Morris water maze test}

The water maze test is also a commonly accepted method for memory test, and we performed this test as described by Morris et al. [27]. Maze testing was fulfilled by the SMART-CS (Panlab, Barcelona, Spain) program and equipment. A circular plastic pool (height; $35 \mathrm{~cm}$, diameter; $100 \mathrm{~cm}$ ) was filled with squid-ink water kept at $22-25{ }^{\circ} \mathrm{C}$. An escape platform (height; $14.5 \mathrm{~cm}$, diameter; $4.5 \mathrm{~cm}$ ) was submerged $1-1.5 \mathrm{~cm}$ below the surface of the water in position. On training trials, the mice were placed in a pool of water and allowed to remain on the platform for $10 \mathrm{~s}$ and were then returned to the cage. The mice that did not find the platform within $120 \mathrm{~s}$ were placed on the platform for $3 \mathrm{~s}$ at the end of the trial. Then mice stay on the platform for seven more seconds. These trials were performed on a single platform and in three starting positions of rotational starting. Escape latency, escape 


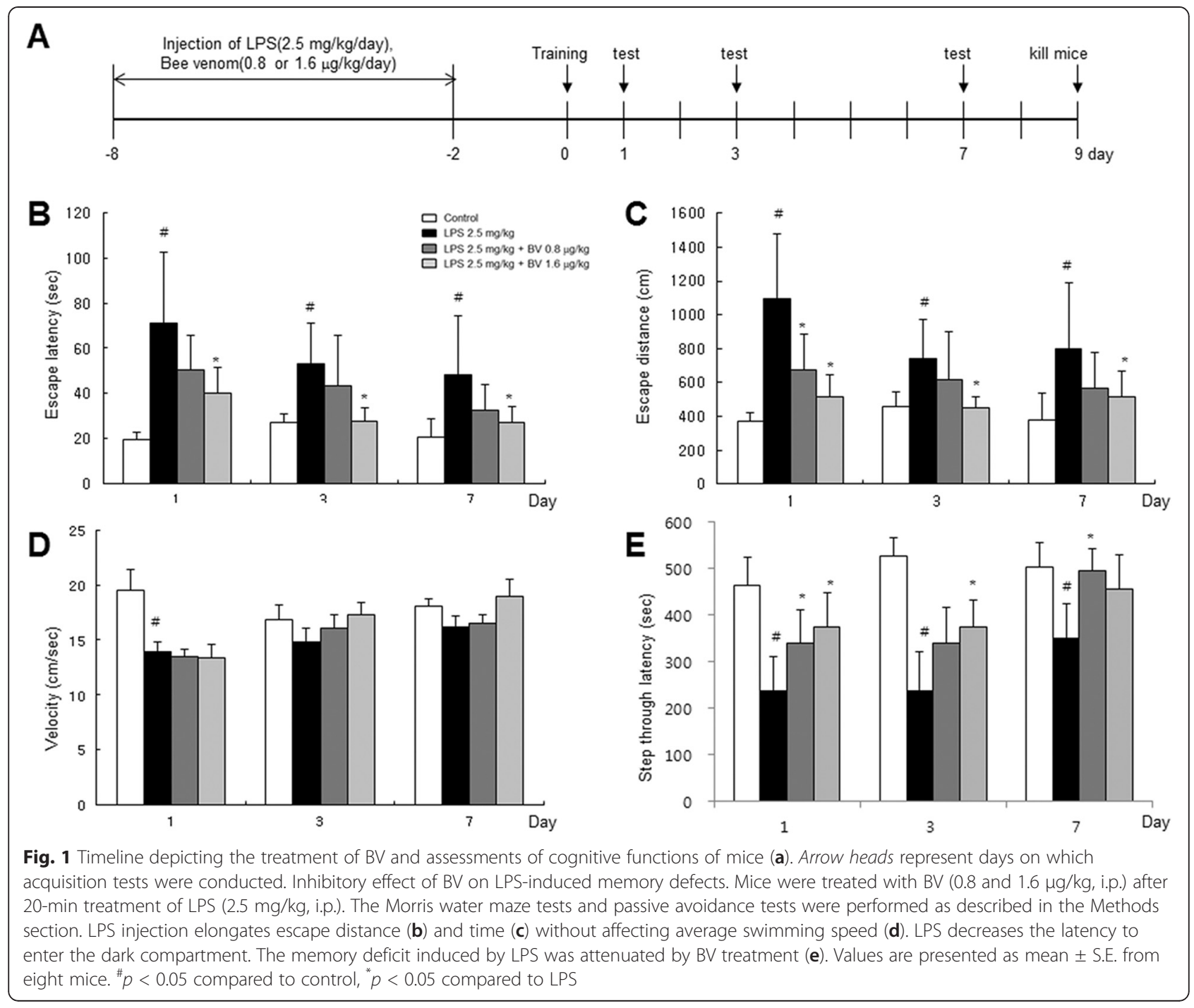

distance, swimming speed, and swimming pattern of each mouse was monitored by a camera above the center of the pool connected to a SMART-LD program (Panlab, Barcelona, Spain).

\section{Passive avoidance performance test}

The passive avoidance test is generally accepted as a simple method for memory testing. The passive avoidance response was determined using a "step-through" apparatus (Med Associates Inc, Vermont, USA) that is consisted of an illuminated and a dark compartment (each $20.3 \times 15.9 \times 21.3 \mathrm{~cm}$ ) adjoining each other through a small gate with a grid floor, $3.175-\mathrm{mm}$ stainless steel-rod set $8 \mathrm{~mm}$ apart. On the first day, the mice were placed in the illuminated compartment facing away from the dark compartment for the training trial. When the mice moved completely into the dark compartment, they received an electric shock (2 mA, 3-s duration).
Then the mice were returned to their case. From training day after 1,3 , and 7 days, the mice were placed in the illuminated compartment and the latency period to enter the dark compartment defined as "retention" was measured. The time when the mice entered into the dark compartment was recorded and described as stepthrough latency. The retention trials were set at a limit of 10 min of cutoff time.

\section{Brain collection and preservation}

After behavioral tests, mice were perfused with phosphate-buffered saline (PBS, $\mathrm{pH}$ 7.4) under inhaled diethyl ether anesthetization. The brains were immediately pulled from the skull, cut, and divided into the left brain and right brain. One hippocampus was removed and stored at $-80{ }^{\circ} \mathrm{C}$, the others were fixed in $4 \%$ paraformaldehyde for $48 \mathrm{~h}$ at $4{ }^{\circ} \mathrm{C}$ and transferred to $30 \%$ sucrose solutions. 


\section{Astrocytes and microglial BV-2 cell culture}

Astrocytes were prepared from the cerebral cortex of rat embryos (E18). After removal of the exception of the cerebral cortex, the cerebral cortex was dissociated into a single-cell suspension by trypsinization and mechanical disruption. The cells were seeded on T-75 culture flasks and incubated in Dulbecco's modified eagle medium (DMEM/F-12) (Invitrogen, Carlsbad, CA) containing $10 \%$ fetal bovine serum (FBS) (Invitrogen). The culture medium was replaced at every 3 days thereafter. After 10-12 days, the cultures became confluent, and loosely attached microglia and oligodendrocyte precursor cells were removed from the cell monolayer through use of a shaking incubator $\left(37^{\circ} \mathrm{C}, 350 \mathrm{RPM}, 2-4 \mathrm{~h}\right)$. Astrocytes were subsequently detached using trypsin-EDTA and plated into $100-\mathrm{mm}$ cell culture dishes. The percentage of astrocytes in our culture system is more than $95 \%$. Microglial BV-2 cells were maintained with serumsupplemented culture media of DMEM supplemented with FBS $(10 \%)$ and penicillin (100 units $/ \mathrm{ml})$. The microglial BV-2 cells were incubated in the culture medium in a humidified incubator at $37{ }^{\circ} \mathrm{C}$ and $5 \%$ $\mathrm{CO} 2$. The cultured cells were treated simultaneously with LPS $(1 \mu \mathrm{g} / \mathrm{ml})$ and several concentrations $(0.5$, $1,2 \mu \mathrm{g} / \mathrm{ml}$ ) of BV dissolved in distilled water, and the cells were harvested after $48 \mathrm{~h}$.

\section{Immunohistochemical staining}

After being transferred to $30 \%$ sucrose solutions, brains were cut into $30-\mu \mathrm{m}$ sections by using a cryostat microtome (Leica CM 1850; Leica Microsystems, Seoul, Korea). After two washes in PBS (pH 7.4) for each 10 min, endogenous peroxidase activity was quenched by incubating the samples in $3 \%$ hydrogen peroxide in PBS for $20 \mathrm{~min}$, and two washes in PBS for each $10 \mathrm{~min}$. The brain sections were blocked for $1 \mathrm{~h}$ in $5 \%$ bovine serum albumin (BSA) solution and incubated overnight at $4{ }^{\circ} \mathrm{C}$ with a mouse polyclonal antibody against glial fibrillary acidic protein (GFAP) (1:300; Santa Cruz Biotechnology, Inc., Santa Cruz, CA, USA), inducible nitric oxide synthase (iNOS) (1:300; Novus Biologicals, Inc., Littleton), a rabbit polyclonal antibody against cyclooxygenase-2 (COX-2) (1:300; Cell Signaling Technology, Inc., Beverly, MA, USA), and a goat polyclonal antibody against ionize calcium-binding adapter molecule 1 (IBA-1) (1:300; Abcam, Inc., Cambridge, MA, USA). After incubation with the primary antibodies, brain sections were washed thrice in PBS for each 10 min. After washing, brain sections were incubated for $1-2 \mathrm{~h}$ at room temperature with the biotinylated goat anti-rabbit or goat anti-mouse or donkey anti-goat IgG-horseradish peroxidase (HRP) secondary antibodies (1:500; Santa Cruz Biotechnology, Inc., Santa Cruz, CA, USA). Brain sections were washed thrice in PBS for each $10 \mathrm{~min}$ and visualized by chromogen DAB (Vector Laboratories) reaction for up to $10 \mathrm{~min}$. Finally, brain sections were dehydrated in ethanol, cleared in xylene, mounted with Permount (Fisher Scientific, Hampton, $\mathrm{NH}$ ), and evaluated on a light microscopy (Olympus, Tokyo, Japan) $(\times 50$ or $\times 200)$.

\section{Fluorescence microscopy}

The fixed cells and brain sections were exposed to the following primary antibodies: GFAP (1:100, Santa Cruz Biotechnology Inc. Santa Cruz, CA, USA), IBA-1 (Abcam, Inc., Cambridge, MA, USA), and $A \beta_{1-42}$ (1:100, Cell Signaling Technology, Inc. Beverly, MA) at room temperature for $2 \mathrm{~h}$. After incubation, the cells were washed twice with ice-cold PBS and incubated with an anti-rabbit or mouse or goat secondary antibody conjugated to Alexa Fluor 488 or 568 (Invitrogen-Molecular Probes, Carlsbad, CA) at room temperature for $1 \mathrm{~h}$. Immunofluorescence images were acquired using an inverted fluorescent microscope Zeiss Axiovert $200 \mathrm{M}$ (Carl Zeiss, Thornwood, NY) $(\times 200)$.

\section{Thioflavin S staining}

After being transferred to $30 \%$ sucrose solutions, brains were cut into $30-\mu \mathrm{m}$ sections by using a cryostat microtome (Leica CM 1850; Leica Microsystems, Seoul, Korea). After washes in distilled water for $5 \mathrm{~min}$, the brain sections were transferred to gelatin-coated slices and placed in $1 \%$ thioflavin $\mathrm{S}$ for $5 \mathrm{~min}$. After this, the brain sections were washed in distilled water then dehydrated through ascending grades of ethanol, 50, 70, 90, and $100 \%$ ethanol for 2 min in each grade. The sections were then mounted in a mounting medium (Fluoromount ${ }^{\text {max }}$ Aqueous Mounting Medium, Sigma, St Louis, MO, USA). The thioflavin $S$ staining was examined using a fluorescence microscope $(\times 100)$.

\section{DAPI/TUNEL assay}

The terminal deoxynucleotidyl transferase (TdT)-mediated dUTP-biotin nick end-labeling (TUNEL) assays were performed by using the in situ cell death detection kit (Roche Diagnostics GmbH, Mannheim, Germany) according to the manufacturer's instructions. TUNEL mixture was added onto tissue sections and incubated in a humidified chamber for $60 \mathrm{~min}$ at $37{ }^{\circ} \mathrm{C}$. After each step, the tissue sections were rinsed twice with PBS (pH 7.4). For DAPI staining, tissue sections were incubated for $30 \mathrm{~min}$ at room temperature in the dark. The cells were then observed through a fluorescence microscope Zeiss Axiovert 200 M (Carl Zeiss, Thornwood, NY). The total number of cells in the given area was determined by using DAPI nuclear staining. The apoptotic bodies (TUNEL-stained cells) were identified under a fluorescence microscope $(\times 200)$ containing green-colored nuclei. The quantity of apoptotic 
bodies was expressed as the average number of apoptotic cells per high-power field (visible apoptotic cells/HPE).

\section{Measurement of $A \beta_{1-42}$}

Lysates of brain tissue were obtained through protein extraction buffer containing protease inhibitor. $A \beta_{1-42}$ levels were determined using each specific ELISA Kit (Immuno-Biological Laboratories Co., Ltd., Takasaki-Shi, Gunma, Japan). Protein was extracted from brain tissues (hippocampus regions), cultured astrocytes, and microglial BV-2 cells using protein extraction buffer (PROPREPTM, Intron Biotechnology, Korea), incubated on ice for $1 \mathrm{~h}$ and centrifuged at $13,000 \mathrm{~g}$ for $15 \mathrm{~min}$ at $4{ }^{\circ} \mathrm{C}$. In brief, $100 \mu \mathrm{l}$ of sample was added into a precoated plate and incubated overnight at $4{ }^{\circ} \mathrm{C}$. After washing each well of the precoated plate with a washing buffer, $100 \mu \mathrm{l}$ of labeled antibody solution was added, and the mixture was incubated for $1 \mathrm{~h}$ at $4{ }^{\circ} \mathrm{C}$ in the dark. After washing, chromogen was added, and the mixture was incubated for $30 \mathrm{~min}$ at room temperature in the dark. Finally, the resulting color was assayed at $450 \mathrm{~nm}$ using a microplate absorbance reader Sunrise $^{\mathrm{Tu}}$, Tecan, Switzerland) after adding stop solution.

\section{Assay of $\beta$ - and $\gamma$-secretase activities}

$\beta$ - and $\gamma$-secretase activity in mice brains was determined using a commercially available $\beta$ - and $\gamma$-secretase activity kit (Abcam, Inc, Cambridge, MA, USA). Protein was extracted from brain tissues (hippocampus regions) using protein extraction buffer (PRO-PREP ${ }^{\mathrm{ms}}$, Intron Biotechnology, Korea), incubated on ice for $1 \mathrm{~h}$, and centrifuged at $13,000 \mathrm{~g}$ for $15 \mathrm{~min}$ at $4{ }^{\circ} \mathrm{C}$. The supernatant was collected. A total of $50 \mu$ of sample (total protein $100 \mu \mathrm{g}$ ) was added to each well followed by $50 \mu \mathrm{l}$ of $\times 2$ reaction buffer and $2 \mu \mathrm{l}$ of $\beta$-secretase substrate incubated in the dark at $37{ }^{\circ} \mathrm{C}$ for $2 \mathrm{~h}$. Fluorescence was read at excitation and emission wavelengths of 355 and $510 \mathrm{~nm}$, respectively, using a Fluostar Galaxy fluorimeter (BMG Lab Technologies, Offenburg, Germany) with Felix software (BMG Lab Technologies, Offenburg, Germany). $\beta$ - and $\gamma$-secretase activity is proportional to the fluorimetric reaction and is expressed as nanomole per milligram of protein per minute.

\section{Nuclear extraction and gel mobility shift assay}

Gel mobility shift assay was conducted using a slight modification of a previously described method [28]. In brief, $10 \mu \mathrm{g}$ of nuclear protein of astrocytes was incubated in $25 \mu \mathrm{L}$ of the total volume of incubation buffer (10 mmol/L Tris, pH 7.5, $100 \mathrm{mmol} / \mathrm{L} \mathrm{NaCl}, 1 \mathrm{mmol} / \mathrm{L}$ dithiothreitol, $4 \%$ glycerol, $80 \mathrm{mg} / \mathrm{L}$ salmon sperm DNA) at $4{ }^{\circ} \mathrm{C}$ for $15 \mathrm{~min}$ followed by another 20-min incubation with $9.25 \mathrm{mBq}\left[\gamma_{-}{ }^{32} \mathrm{P}\right]$ ATP-labeled oligonucleotide containing the NF-kB-binding site at room temperature. The DNA protein-binding complex was electrophoretically resolved on a $6 \%$ nondenatured polyacrylamide gel at 150 volts for $90 \mathrm{~min}$. The gels were dried and autoradiographed using Kodak MR film at $-80{ }^{\circ} \mathrm{C}$ overnight.

\section{Pull-down assay}

Melittin was conjugated with Epoxy-activated sepharose 6B (Sigma, St Louis, Missouri, United States). BV (1 mg) was dissolved in $1 \mathrm{~mL}$ of coupling buffer $(0.1 \mathrm{M}$ $\mathrm{NaHCO}_{3}$ and $0.5 \mathrm{M} \mathrm{NaCl}, \mathrm{pH}$ 11). The Epoxy-activated sepharose 6B was swelled and washed in $1 \mathrm{mM}$ of $\mathrm{HCl}$ on a sintered glass filter, then washed with a coupling buffer. Epoxy-activated sepharose 6B beads were added to the melittin containing coupling buffer and incubated at $4{ }^{\circ} \mathrm{C}$ for overnight. After washing, unoccupied binding sites were blocked with $1 \mathrm{M}$ ethanolamine at $4{ }^{\circ} \mathrm{C}$ overnight. The melittin-conjugated sepharose $6 \mathrm{~B}$ was washed with three cycles of alternating $\mathrm{pH}$ wash buffers (buffer 1 ; $0.1 \mathrm{M}$ acetate and $0.5 \mathrm{M} \mathrm{NaCl}, \mathrm{pH}$ 4; buffer 2; $0.1 \mathrm{M}$ Tris$\mathrm{HCl}$ and $0.5 \mathrm{M} \mathrm{NaCl}, \mathrm{pH}$ 8). Melittin-conjugated beads were then equilibrated with a binding buffer $(0.05 \mathrm{M}$ Tris$\mathrm{HCl}$ and $0.15 \mathrm{M} \mathrm{NaCl}, \mathrm{pH} 7.5)$. The control unconjugated Epoxy-activated sepharose 6B beads were prepared as described above with the absence of melittin. BV-2 cell lysates were prepared in a lysis buffer of PRO-PREBP. The cell lysates ( $1 \mathrm{mg}$ of protein) were mixed with $20 \mu \mathrm{l}$ of melittinconjugated sepharose $6 \mathrm{~B}$ or sepharose $6 \mathrm{~B}$ at $4{ }^{\circ} \mathrm{C}$ overnight. The beads were then washed three times with TBST. The bound proteins were eluted with SDS-loading buffer. The proteins were then resolved by SDS-PAGE followed by immunoblotting with antibodies against p50 (1:1000, Santa Cruz Biotechnology Inc. Santa Cruz, CA, USA).

\section{Molecular modeling}

Docking studies between melittin and p50 of NF- $\mathrm{kB}$ subunit were performed using Autodock VINA [29]. Threedimensional structures of the NF-kB-DNA complexes were retrieved from the Protein Data Bank (PDB codes; 1VKX), and melittin was retrieved from the PDB (PDB codes; 2MLT). Starting from the co-crystallized complexes, the NF- $\mathrm{kB}$ p50 monomer chain (p50 from 1VKX), melittin (melittin from 2MLT) for docking, were prepared using Maestro graphical interface. The grid box was centered on the p50 monomer, and the size of the grid box was adjusted to include the whole monomer. Docking experiments were performed at various exhaustiveness values of the default, 16, 24, 32, 40, and 60. Molecular graphics for the best binding model were generated using Discovery Studio Visualizer 2.0.

\section{Western blotting}

The hippocampus tissues, treated astrocytes, and microglial BV-2 cells were homogenized with lysis buffer 
(PRO-PREP; iNtRON, Seongnam, Korea), incubated on ice for $30 \mathrm{~min}$, and centrifuged at 13,000 $\mathrm{g}$ for $15 \mathrm{~min}$ at $4{ }^{\circ} \mathrm{C}$. Cytosol protein was extracted using buffer A (50 mM HEPES, pH 7.4, $10 \mathrm{mM} \mathrm{KCl,} 1 \mathrm{mM}$ EDTA, $1 \mathrm{mM}$ EGTA, $1 \mathrm{mM}$ dithiothreitol, $0.1 \mathrm{mg} / \mathrm{ml}$ PMSF, $1 \mu \mathrm{g} / \mathrm{ml}$ pepstatin A, $1 \mathrm{mg} / \mathrm{ml}$ leupeptin, $10 \mu \mathrm{g} / \mathrm{ml}$ soybean trypsin inhibitor, $10 \mu \mathrm{g} / \mathrm{ml}$ aprotinin, and $0.5 \%$ Nonidet P-40), incubated on ice for 10-15 min, and centrifuged at $6000 \mathrm{~g}$ for $10 \mathrm{~min}$ at $4{ }^{\circ} \mathrm{C}$. This supernatant is cytosol extract. Buffer C (buffer A $+10 \%$ glycerol and $400 \mathrm{mM} \mathrm{KCl}$ ) was added to the pellet, incubated on ice for $30 \mathrm{~min}$, and centrifuged at $13,000 \mathrm{~g}$ for $15 \mathrm{~min}$ at $4{ }^{\circ} \mathrm{C}$. This supernatant is nuclear extract. An equal amount of total protein $(40 \mu \mathrm{g})$ was resolved on $6-$ $15 \%$ sodium dodecyl sulfate polyacrylamide gel and then transferred to a nitrocellulose membrane (Hybond ECL; Amersham Pharmacia Biotech, Piscataway, NJ, USA). The membranes were blocked for $1 \mathrm{~h}$ in $5 \%$ skim milk solution and incubated overnight at $4{ }^{\circ} \mathrm{C}$ with specific antibodies. To detect target proteins, specific antibodies against APP, iNOS (1:1000, Novus Biologicals, Inc., Littleton), BACE1, IBA-1 (1:1000, Abcam, Inc., Cambridge, MA, USA), COX-2 (1:1000, Cell Signaling Technology, Inc., Beverly, MA, USA), GFAP, p50, p65, IкB, phospho-IкB, $\beta$-actin, and Histone H1 (1:1000, Santa Cruz Biotechnology Inc. Santa Cruz, CA, USA) were used. The blots were then incubated with the corresponding conjugated goat anti-rabbit or goat anti-mouse or donkey anti-goat IgG-horseradish peroxidase (HRP) (1:5000; Santa Cruz Biotechnology Inc. Santa Cruz, CA, USA) secondary antibodies. Immunoreactive proteins were detected with an enhanced chemiluminescence western blotting detection system. The relative density of the protein bands was scanned by densitometry using MyImage (SLB, Seoul, Korea) and quantified by Labworks 4.0 software (UVP Inc., Upland, CA, USA).

\section{Statistical analysis}

Measurement of the image data used Image (Wayne Rasband, National Institutes of Health, Bethesda, MD). Statistical analysis of the data was carried out using analysis of variance (ANOVA) for repeated measures followed by Dunnett's post-hoc analysis using GraphPad Prism 4 software (Version 4.03, GraphPad software, Inc., La Jolla, USA).

\section{Results}

Inhibitory effect of BV on LPS-induced memory defects

Seven- to eight-week old ICR mice were administered with LPS $(2.5 \mathrm{mg} / \mathrm{kg})$ for 7 days to study whether BV could improve memory in LPS-induced AD mice. We used the Morris water maze and passive avoidance performance tests. The mice were trained for three trials per day. Control mice took short escape latency to get to the platform, but LPS-treated mice arrived at the location of the platform more slowly than the control mice, suggesting that the memory deficiency could be induced by LPS as reported previously [30]. BV-treated mice however, exhibited shorter escape latency than LPStreated mice. BV-treated mice with a higher dose showed shorter escape latency than BV-treated mice with a lower dose (Fig. 1b). BV-treated mice also showed shorter escape distance compared to LPS-treated mice (Fig. 1c). However, there was no significant difference in average velocity between LPS-treated mice and BVtreated mice (Fig. 1d). Next, we examined the passive avoidance performance test 1 day after the Morris water maze test. Stay time in the white chamber indicated maintenance of memory capacity. LPS-treated mice $(351.1 \pm 72.9 \mathrm{~s})$ stayed for a shorter time than control mice $(502.0 \pm 52.7 \mathrm{~s})$. BV-treated mice (BV $0.8 \mu \mathrm{g} / \mathrm{kg}$; $495.6 \pm 46.2 \mathrm{~s}$, BV $1.6 \mu \mathrm{g} / \mathrm{kg} ; 454.6 \pm 73.3 \mathrm{~s}$ ) stayed for a longer time than LPS-treated mice but shorter than control mice demonstrating memory recovery effect (Fig. 1e).

\section{Inhibitory effect of BV in LPS-induced amyloidogenesis and $A \beta$ accumulation}

$A D$ is known to be correlated with accumulation of $A \beta$ peptides. Therefore, we examined whether BV reduced LPS-induced A $\beta$ accumulation and amyloidogenesis, and thus recovery memory function. Thioflavin $S$ staining is dyed with beta sheet-rich structures of $A \beta$. This thioflavin $S$ staining was used for detection of $A \beta$ accumulation. The higher accumulation of $A \beta$ was seen in the brain of LPS-treated mice; however, lower accumulation of $A \beta$ was seen in the BV-treated mice brain (Fig. 2a). We also used immunohistochemistry for detection of $A \beta$ expression and acquired the same results as thioflavin $\mathrm{S}$ staining (Fig. 2b). We analyzed the expression of APP and BACE1 by western blotting. LPS-treated mice increased the expression of these proteins, but BV-treated mice showed decreased expressions (Fig. 2c). To clarify how amyloidogenesis was reduced by BV, we analyzed the amount of $A \beta_{1-42}$ level and $\beta$ - and $\gamma$-secretase activities in whole brain. The level of $A \beta_{1-42}$ and activities of $\beta$ - and $\gamma$-secretase were significantly increased in LPStreated mice brain, while these level and activities were decreased in BV-treated mice brain (Fig. 2d-f). Because the activation of astrocytes is implicated in the activation of $\beta$-secretase, we investigated whether the numbers of astrocytes (GFAP-positive cells) and the accumulation of $A \beta$ are concomitantly increased by LPS, and whether BV reduces astrocytes activation, thereby reducing $A \beta_{1-42}$ levels. The immunoreactive cells for both GFAP and $A \beta_{1-42}$ were identified using a double immunofluorescence method. The co-reactive cell number for both markers was increased by LPS, but was lowered by BV 


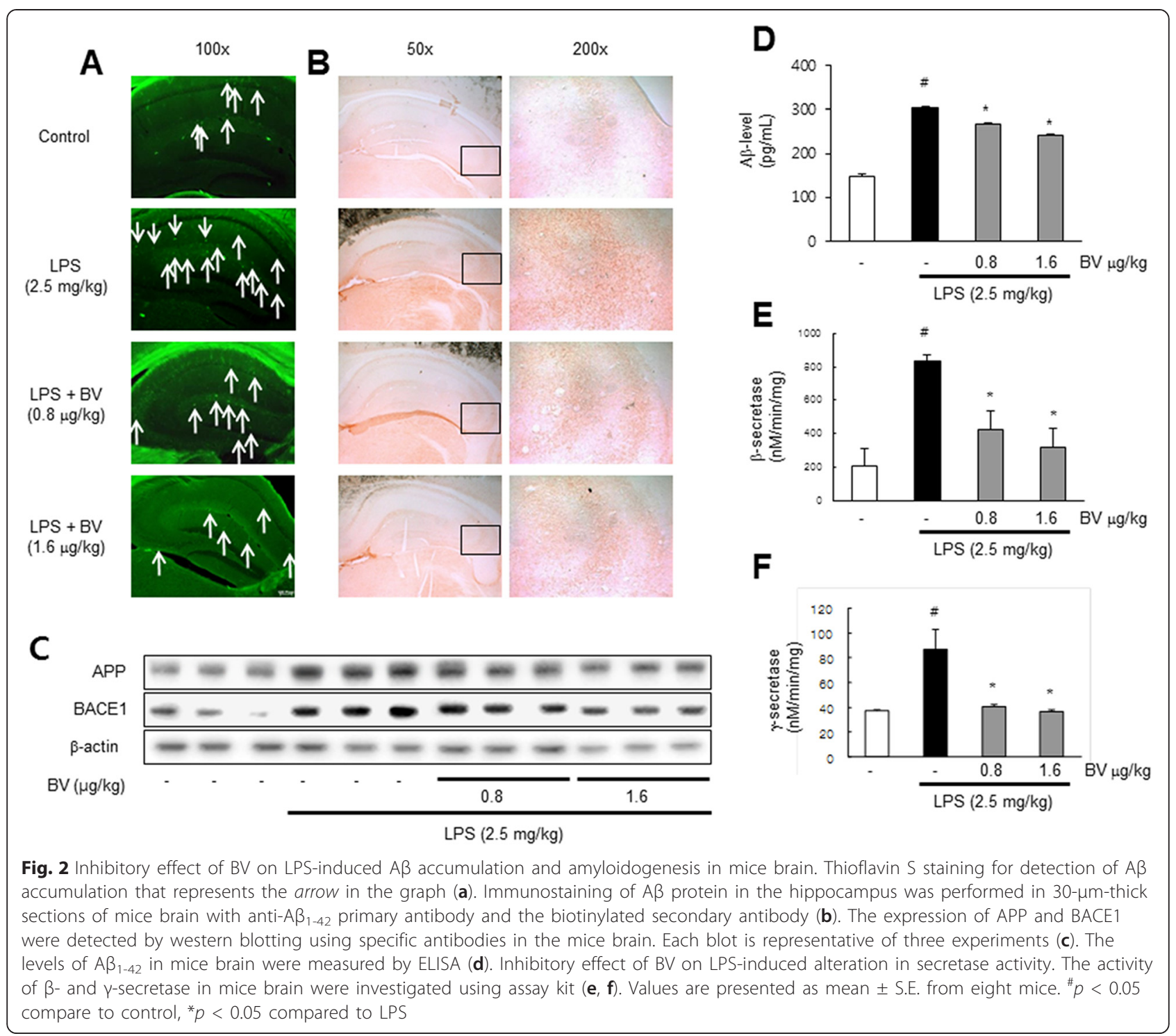

treatment (Fig. 3a). In addition, we further studied into microglia cells. The double positive cell number for $A \beta$ accumulation in microglia cells (IBA-1-positive cells) was increased by LPS, which was also lowered by BV treatment (Fig. 3b).

Inhibitory effect of BV on LPS-induced neuronal cell death and neuroinflammation

To observe death of brain cells, we used the DAPI/ TUNEL assay. Apoptosis (\%) was defined as the percentage of the number of TUNEL-positive cells per surface of unit. TUNEL-stained brain cells were more in LPStreated mice brain $(61.0 \pm 1.8)$ compared to control $(8.6 \pm 1.4)$ and BV-treated mice brain. BV-treated mice brain values were $26.6 \pm 4.1(0.8 \mu \mathrm{g} / \mathrm{kg})$, and $22.3 \pm 1.7$ $(1.6 \mu \mathrm{g} / \mathrm{kg}$ ), respectively (Fig. 4).
Activated NF- $\mathrm{kB}$ by LPS can trigger neuroinflammation in neuronal cells through activation of inflammatory cells such as astrocytes and microglia cells. To confirm activation of astrocytes and microglia cells, we used the immunohistochemistry and western blotting to detect the expression of GFAP (a marker of astrocyte activation), IBA-1 (a marker of microglia cell activation), iNOS, and COX-2 in the brain. The results showed that LPS-treated mice brain increased expression of these proteins in comparison with control; however, expression of these proteins was decreased in BV-treated mice brain (Fig. 5a, b).

Inhibitory effect of BV on LPS-induced NF-KB activation To determine whether BV is able to inhibit LPS-induced DNA-binding activity of NF- $\mathrm{kB}$ in the mice model, 


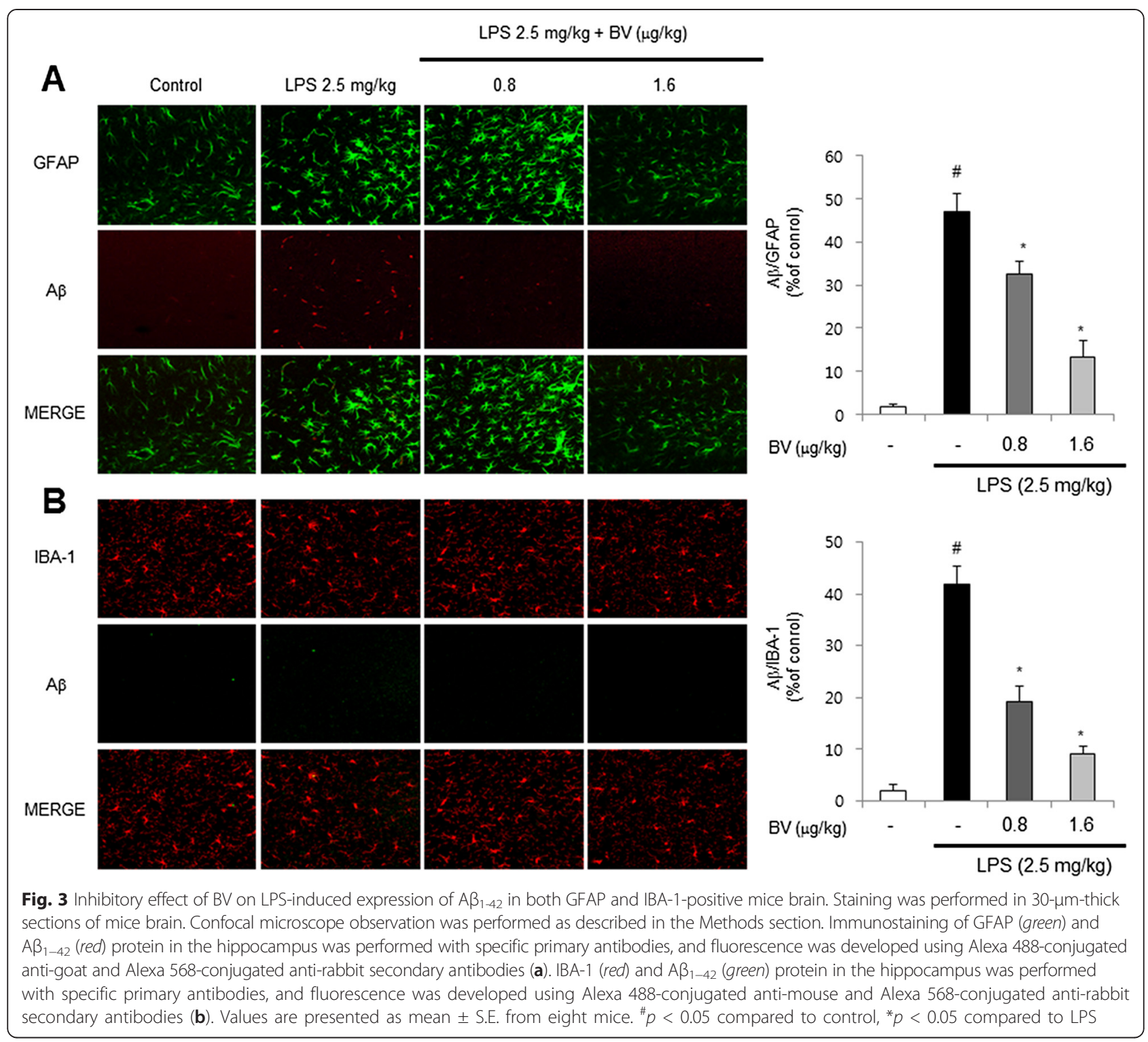

nuclear extracts from mice brain were prepared and assayed for NF-kB DNA-binding activity by EMSA (Fig. 6a). LPS significantly induced NF-kB; however, its activity was effectively blocked by BV. When treated with LPS, we found that NF-kB proteins (p50 and p65) were translocated to the nucleus, and IкB was phosphorylated, while BV remarkably inhibited LPS-induced translocation of p50 and p65 in the nucleus as well as I $\mathrm{B}$ phosphorylation in a dose-dependent manner in mice brain (Fig. 6b).

\section{Interaction between melittin and p50 of the NF-KB subunit}

To investigate whether the inhibitory effect of BV on activity due to direct binding of melittin, a major component of BV (Fig. 6c), and p50, a subunit of NF- $\mathrm{kB}$, we performed a pull-down assay and molecular docking experiment between melittin and p50 of the NF- $\mathrm{kB}$ subunit using melittin-sepharose $4 \mathrm{~B}$ beads. The binding of melittin to p50 was then detected by immunoblotting with an anti-p50 antibody. The results indicated that melittin interacted with cell lysates containing p50 from microglial BV-2 cells as well as recombinant p50 protein (Fig. 6d). To identity the binding site of p50 to melittin, we performed computational docking experiments with melittin and $\mathrm{p} 50$. The binding study was performed using Autodock Vina software and showed that melittin binded near to the C-terminus of p50 (melittin binds to Tyr387, Vol388, Pro39, Lys392, Thr424, Pro427, Lys428, Thr522, Ser524, and Phe525 of p50) where nuclear localization signal (NLS) is located in this specific p50 (Fig. 6e). 


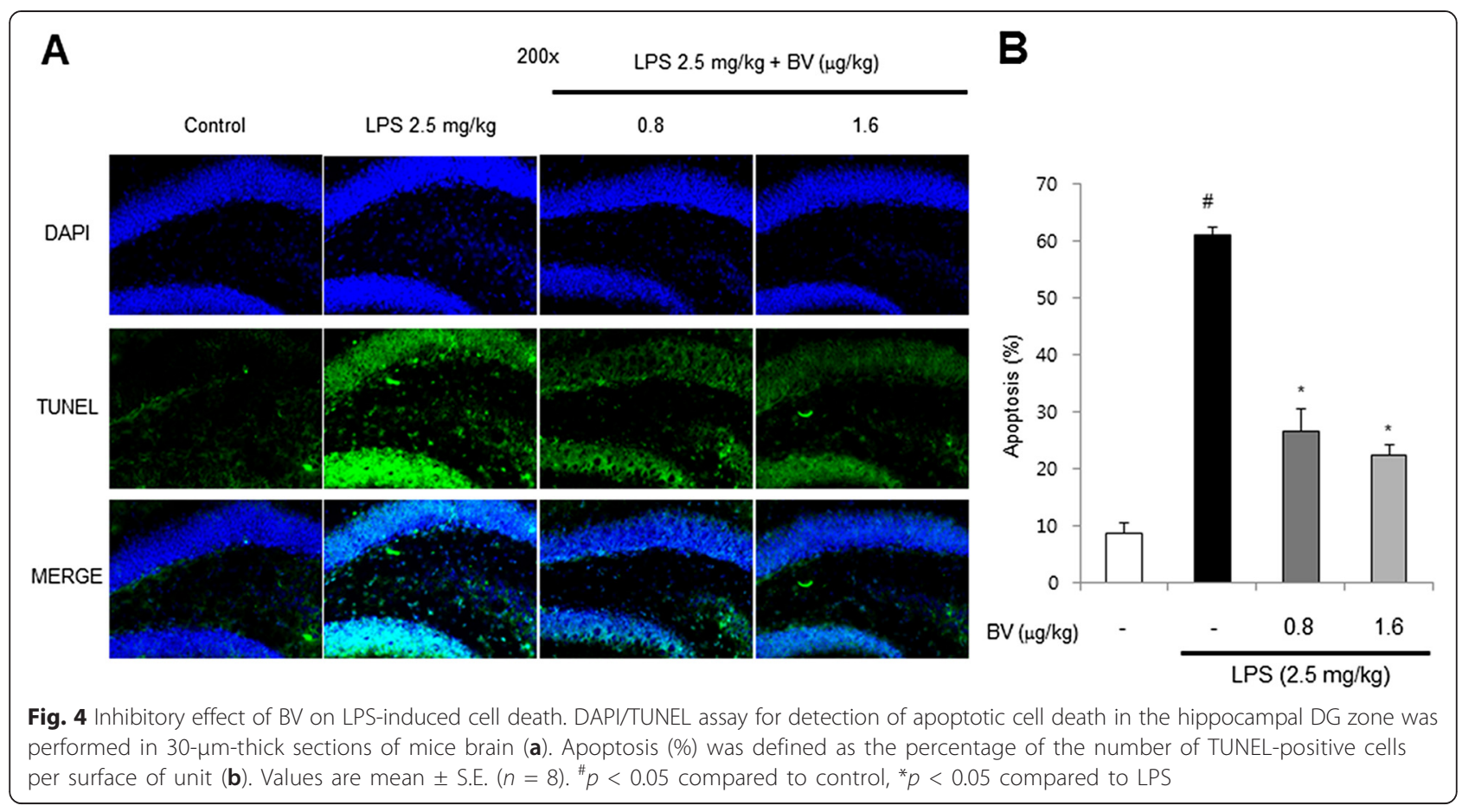

\section{Inhibitory effect of BV on amyloidogenesis and neuroinflammatory responses in astrocytes and microglia cells}

To find anti-amyloidogenesis of BV in primary cultured astrocytes (Fig. 7a) and microglial BV-2 cells, both cells were treated with $1 \mu \mathrm{g} / \mathrm{mL}$ of LPS and $0.5,1$ and $2 \mu \mathrm{g} / \mathrm{mL}$ of BV (Fig. 7b) and then detected APP and BACE1 expression by western blotting. LPS-treated cells increased expression of APP and BACE1 than control, but BV-treated cells clearly decreased expression of APP and BACE1 than LPS-treated cells. Moreover, the LPS-induced $A \beta_{1-42}$ level was decreased by the treatment of BV determined by ELISA (Fig. 7c, d). We also discovered that BV inhibited LPS-induced NF- $\kappa \mathrm{B}$ activity, translocation of NF- $\mathrm{B}$ proteins ( $\mathrm{p} 50$ and p65) to the nucleus and $I_{\kappa} B$ phosphorylation in both cells (Fig. $7 \mathrm{~g}, \mathrm{~h}$ ). The expression of inflammatory proteins (iNOS, COX-2, GFAP, and IBA-1) was also detected by western blotting using specific antibodies. The BV attenuated LPS-induced increased expression of inflammatory proteins in a dose-dependent manner (Fig. $7 \mathrm{i}, \mathrm{j}$ ). On the same principle as brain sections, we detected double immunofluorescence in both cells by confocal microscope analysis. Co-expression of GFAP (astrocytes marker) and $A \beta_{1-42}$ was increased by LPS but was decreased by BV treatment in primary cultured astrocytes (Fig. 8a). Co-expression of IBA-1 (microglia cell marker) and $\mathrm{A} \beta_{1-42}$ in microglial $\mathrm{BV}-2$ cells showed the same results as primary cultured astrocytes (Fig. 8b).

\section{Discussion}

Increasing $A \beta$ accumulation and neuroinflammation in the brain contributes to the onset development of $\mathrm{AD}$ by causing neuronal cell death [2, 3]. Our study showed that BV prevented LPS-induced memory impairment. Significantly, BV ameliorated LPS-mediated amyloidogenesis and neuroinflammatory reactions in the brain as well as cultured inflammatory neuronal cells, thus memory improvement through direct inhibition of NF-kB. These data indicate that BV could be useful for treatment of AD. Our previous study revealed that LPS injection caused amyloidogenesis and memory loss in mice brain through NF- $\mathrm{kB}$ activation [30]. The aging process is a potential contributor to the accumulation of $A \beta$ and other risk factors of AD. Recent study also demonstrated that the neuroinflammatory response to surgery causes postoperative cognitive dysfunction via the activation of $\mathrm{AD}$ pathogenic mechanisms such as gliosis, microgliosis, astrogliosis, enhanced production of $A \beta$, and $\tau$ protein phosphorylation in old subjects [31]. For these reasons, the elder mice are more effective for the study of $A D$ pathology. But, in the present study, we used seven- to eight-week old mice because we already showed that the AD pathogical changes were found in 7-10 weeks after treatment of LPS $(2.5 \mathrm{mg} / \mathrm{kg})[26,30,32,33]$. NF-кB activates the transcription of APP, BACE1, and $\gamma$-secretase and therefore increases generation of $A \beta$ because NF- $\mathrm{B}$ is a transcription factor of these genes [13, 34]. Our recent studies demonstrated that melittin, a major component of BV, inhibited LPS-induced NF- $\mathrm{kB}$ activation by 


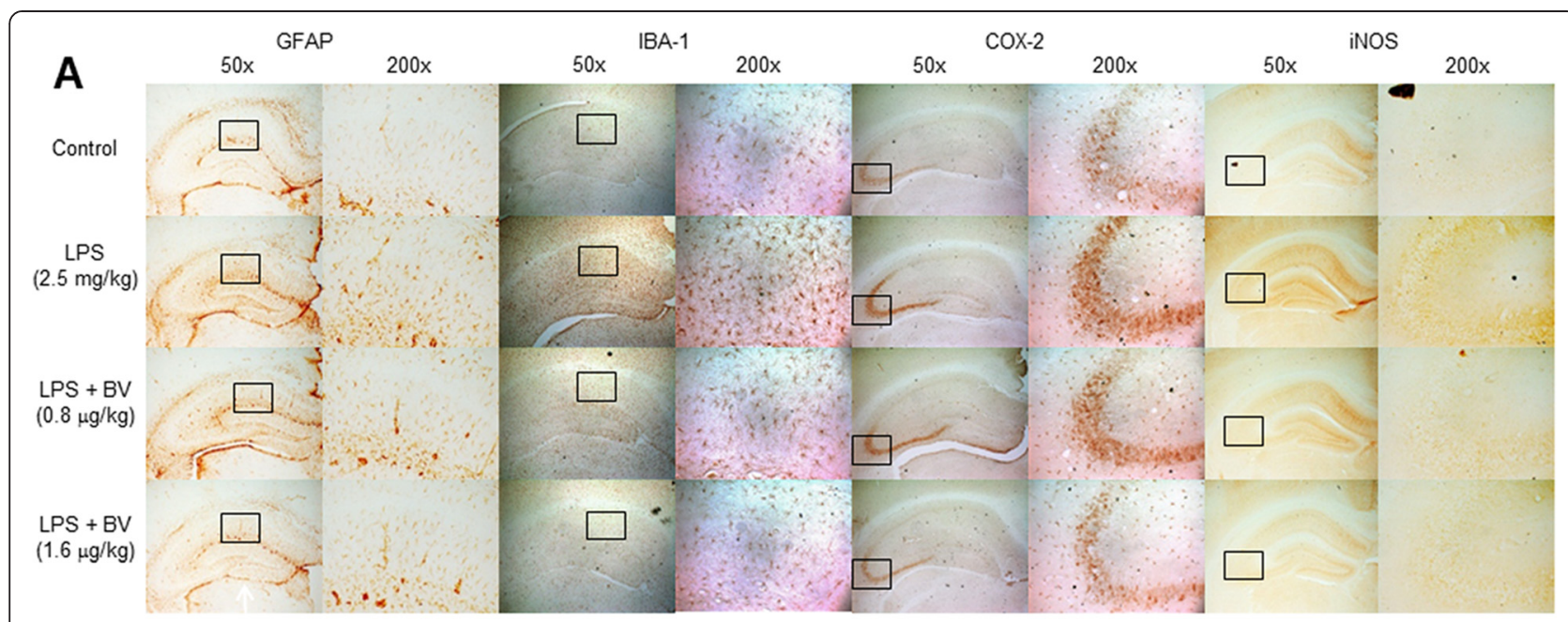

B

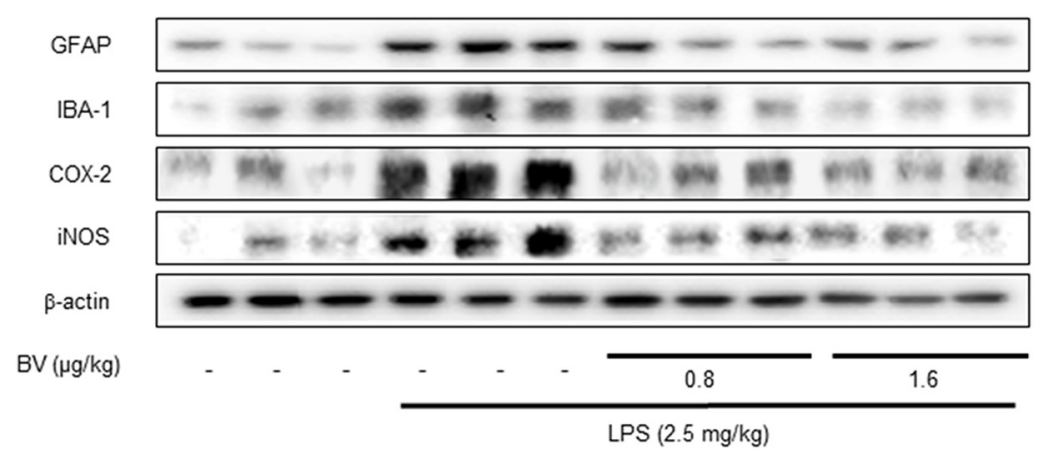

Fig. 5 Inhibitory effect of BV on LPS-induced brain cell activation and neuroinflammation. Immunostaining of GFAP, IBA-1, COX-2, and iNOS proteins in the hippocampus were performed in 30- $\mu$ m-thick sections of mice brain with specific primary antibodies and the biotinylated secondary antibodies $(n=8)$ (a). The expression of GFAP, IBA-1, COX-2, and iNOS were detected by western blotting using specific antibodies in the mice brain. Each blot is representative of three experiments $(\mathbf{b})$

interrupting p50 translocation through interaction with sulfhydryl residue of $\mathrm{p} 50$ or IKK [23, 24]. Our present study also showed that BV reduced LPS-induced DNAbinding activities of NF- $\mathrm{kB}$, interrupting p50 and p65 translocation through preventing I $\mathrm{B}$ phosphorylation in mice brain as well as cultured astrocytes and microglia cells. Thus, the inhibiting effect of BV on NF-kB activity could result in anti-amyloidogenesis. Similar to the present study, our previous studies also showed that thiacremonone and 4-O-methylhonokiol inhibited transcriptional and DNA-binding activity of NF- $\mathrm{kB}$ via inhibition of $\mathrm{I} \kappa \mathrm{B}$ degradation as well as p50 and p65 translocation into the nucleus of the brain and cultured astrocytes and microglial BV-2 cells, and thus these compounds enhance memory function by anti-amyloidogenic effects $[14,30]$. Huang $X$. et al. showed inhibition of the accumulation of $A \beta$ through inhibition of IKK activation, IkB degradation, and the subsequent NF-kB activation [35]. These results demonstrated that direct binding of melittin, a major component of BV, to p50 results in the inhibitory effect of $\mathrm{BV}$ on $\mathrm{NF}-\mathrm{kB}$, and inhibition of NF-kB could be significant for the antiamyloidogenic effect of BV.

Anti-amyloidogenesis effect of BV was associated with decreases of expression of inflammatory response genes such as iNOS and COX-2. Guo et al. demonstrated that neuroinflammation plays an important role in the process of amyloid deposition [36]. Deng et al. also showed that LPS-induced neuroinflammation was associated with amyloidogenesis in adult rat brains [37]. Neuroinflammation is associated with a broad spectrum of neurodegenerative diseases including $\mathrm{AD}$ [38]. It has been shown that there are increases in markers of neuroinflammation in AD patients' brain [39]. LPS-induced systemic inflammation has been shown to impair neuronal cells in animal models for AD [9, 30, 40]. Actually, LPS kills neurons after treatment of high concentrations and long-term periods of LPS. In fact, the induction of neuroinflammation or brain cell death depends on the experimental injection method, concentration, and periods of LPS treatment. Recent study demonstrated that long-term sustainable (16th day after LPS injections) 


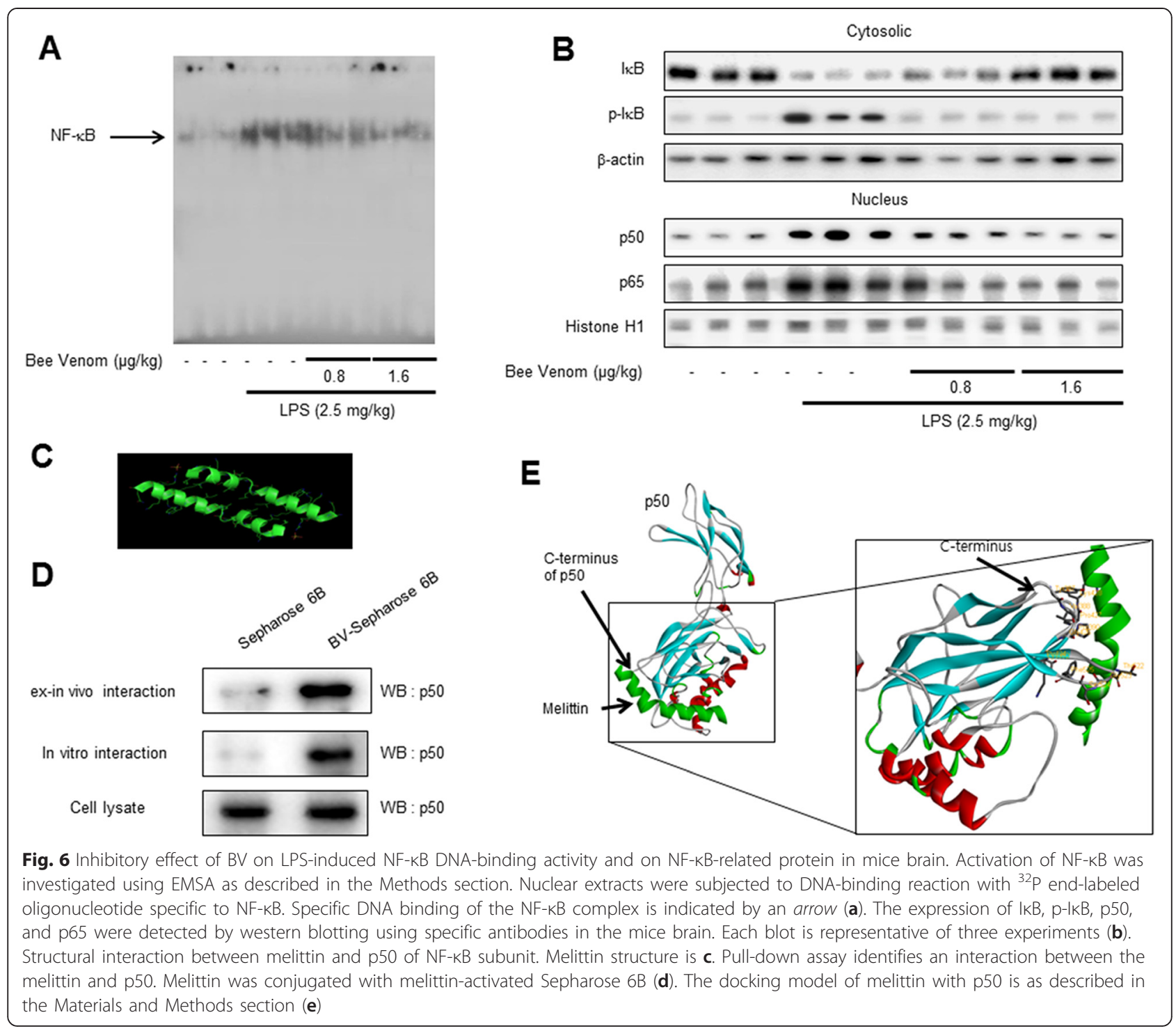

activation of astroglial NF-kappaB following systemic inflammation by LPS $(10 \mathrm{mg} / \mathrm{kg})$ was associated with brain cell and microvasculature injury in the sub-region of the hippocampus which ultimately likely results in brain functional impairment [41]. Lee et al. demonstrated that two different doses of LPS $(0.25$ or $0.75 \mathrm{mg} / \mathrm{kg} /$ day for 7 days) could induce memory dysfunction and amyloidogenesis but did not show significant difference between the two doses (Y.J. Lee, J.A. Kim and J.T. Hong, unpublished observations). We also observed the low concentrations of LPS $(0.25 \mathrm{mg} / \mathrm{kg} /$ day $)$ for 3 to 7 days and found that they were really not much different between 3 and 7 days [9]. It has also been demonstrated that several compounds such as 4-O-methylhonokiol, obovatol, and thiacremonone showed anti-amyloidogenesis and memory-recovering effect in LPS $(0.25 \mathrm{mg} / \mathrm{kg} /$ day for 7 days)-induced amyloidogenesis and memory loss
$[14,30,32]$. Based on these previous data, we used $2.5 \mathrm{mg} / \mathrm{kg}$ for 7 days for the treatment of mice for this present study. Sheng et al. showed that LPSinduced neuroinflammation of APPswe transgenic mice increases levels of APP and A $\beta$ and causes the accumulation of $A \beta$ within the cell bodies of neurons. Neuroinflammation can be caused by excessive activation of astrocytes and microglia cells. Lee et al. showed that activated astrocytes and microglial BV-2 cells by LPS produced TNF- $\alpha$, IL- $1 \beta$, iNOS, and COX-2 in cultured astrocytes and microglial BV-2 cells [42]. It was also reported that the expression of beta APP was elevated by activation of astrocytes and microglia cells in primary cultures of a cerebral cortex from a newborn rat [43]. Thus, inhibition of LPS-induced of neuroinflammation by inactivation of astrocytes and microglia cells by BV could be associated with anti-amyloidogenesis of BV. 


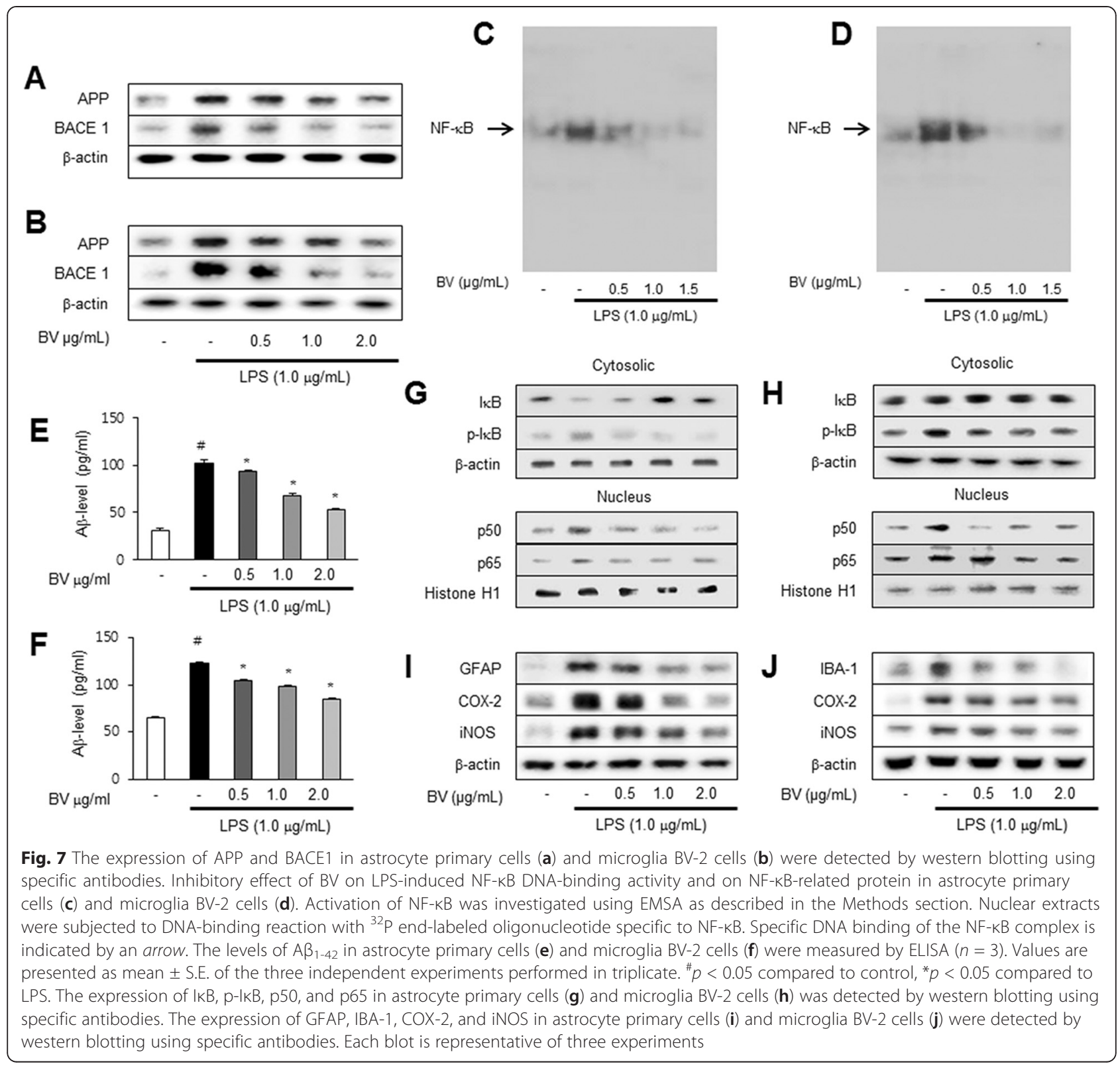

Astrocytes and microglia cells are activated by the activation of NF- $\mathrm{KB}$ [44]. Rolova et al. showed that cultured microglia deficient for the gene (Nfkb1) encoding p50 subunit shows reduced induction of proinflammatory mediators, increased expression of anti-inflammatory genes in response to LPS exposure in microglia cells. They also showed that p50 NF- $\mathrm{kB}^{-/}$mice (Nfkb1-deficient mice) crossed with transgenic Alzheimer mice (APdE9 transgenic mice) reduced $A \beta$ levels [45]. It was proved that NF- $\mathrm{KB}$ is directly involved in the regulation of GFAP gene expression in cultured primary human brain astrocytes [46]. Webster et al. showed decrease in translocation of $\mathrm{p} 65$ in genetic knock-down in vitro via siRNA, or in vivo $\mathrm{P}_{2} \mathrm{Y}_{12}$, microglial purinergic receptor transgenic mice $\left(\mathrm{P}_{12}^{-/-}, \mathrm{P}_{12}^{+/-}\right)$[47]. Wang et al. also showed that 3-N-butylphthalide (NBP) has been reported to attenuate astroglial activation and exert neuroprotective effects in $A D$ transgenic mice by attenuation of $A \beta-$ induced activation of astrocytes and neuroinflammation via inhibition of the NF- $\mathrm{BB}$ signaling pathway $[48,49]$. Our various $\mathrm{AD}$ animal models have shown that activity of NF- $\kappa B$ increased activation of both cells [14, 30, 50, 51]. These data suggest that blocking of NF- $\kappa B$ is also significant for inactivation of astrocytes and microglia cells for preventing neuroinflammation and amyloidogenesis.

The way to inhibit NF- $\mathrm{kB}$ by BV is important for the basic principle for inhibition of NF- $\mathrm{kB}$. In this regard, it is noteworthy that $\mathrm{BV}$ binds to protein of $\mathrm{p} 50$, a subunit 


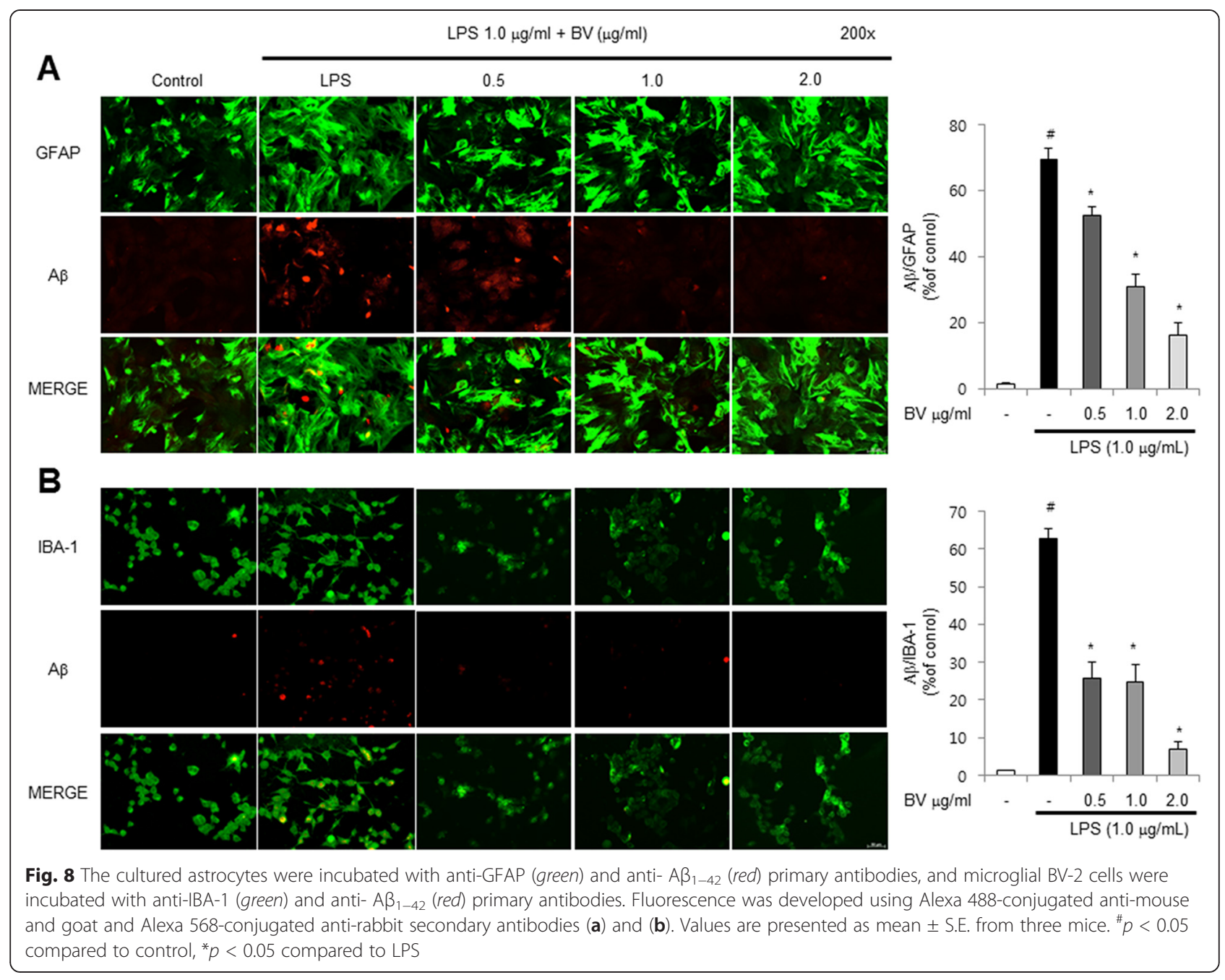

of NF-kB evidenced by pull-down assay and docking model. 7,8-dihydroxy-4-methylcoumarin (7,8-DHMC), 5,7-dihydroxy-4-methylcoumarin (5,7-DHMC) and gallic acid have shown that direct binding to NF- $\mathrm{KB}$ subunits could result in inhibition of NF- $\mathrm{kB}$ activities. 7,8-DHMC and 5,7-DHMC form three hydrogen bonds with DNAbinding region (DBR), but gallic acid makes five hydrogen bonds with DBR [52]. We previously found that the inhibitory effect of BV on NF- $\mathrm{KB}$ due to direct binding of melittin, a major component of BV to p50 subunit (DNA-binding site) of NF- $\mathrm{kB}$, was determined by surface plasmon resonance analyzer [23]. Our present study confirmed that melittin binds to p50 of the NF-KB subunit through the docking model and pull-down assay. However, unlike previous findings, the present study showed that melittin directly binds to the C-terminus of p50 (melittin binds to Tyr387, Vol388, Pro39, Lys392, Thr424, Pro427, Lys428, Thr522, Ser524, and Phe525 of p50) where nuclear localization sequence (NLS) is located. It was reported that blocking NLS is important for inhibition of NF- $\mathrm{kB}$ activity by suppressing nuclear translocation of p50 [53]. Melittin also binds to the dimerization interface of p50 (melittin binds to Arg552, Aso554, Glu565, Tyr567, Leu569, His604, Arg605, Phe607, Val610, and Lys612 of p50); therefore, melittin potentially prevents p50-p65 dimerization, and melittin also can interrupt the nuclear translocation of p50. These data indicated that BV could directly bind to NF- $\kappa B$ ( $\mathrm{p} 50$ ), thus inhibiting NF- $\mathrm{kB}$ activity.

BV has demonstrated the inhibitory effect on rheumatoid arthritis (RA) in a carrageenan rat model and a rat model of chronic adjuvant-induced arthritis, amyotrophic lateral sclerosis (ALS) in a hSOD1G93A mutant mice model, and Parkinson's disease (PD) in a 1-methyl4-phenyl-1,2,3,6-tetrahydropyridine (MPTP)-induced mice model through control of NF- $\mathrm{kB}$ activation $[23,54,55]$. $\mathrm{BV}$ also has shown the cancer cell growth inhibitory effect via inactivation of NF- $\mathrm{KB}$ in non-small cell lung cancer (NSCLS) cells and human prostate cancer cells (LNCaP, DU145, and PC-3) [56, 57]. Moreover, BV and melittin 
inhibited cell proliferation and induced apoptosis in rat aortic vascular smooth muscle cell (VSMC) via suppressions of NF-kB activation [58]. These studies showed that BV could be useful for treatment of several diseases through inhibition of NF- $\mathrm{kB}$ activation. To conclude, our present data indicate that BV could be effective for treatment and/or prevention of the development of diseases such as $\mathrm{AD}$ through anti-amyloidogenesis and antiinflammatory responses by inhibiting NF-kB activation.

\section{Conclusions}

We demonstrated that BV decreased amyloidogenesis and neuroinflammation. This observation was confirmed by expression of GFAP, IBA-1, COX-2, and iNOS. These proteins were decreased in $\mathrm{BV}$ injection groups. We also observed that BV has effect on the inhibition of NF- $\mathrm{B} B$ activation through expression of $\mathrm{I} \kappa \mathrm{B}$, phospho-IкB, p50, and p65. Especially, melittin, a major component of BV, directly binds to the C-terminus of p50 where NLS is located, so they interrupt translocation of NF-kB. Therefore, BV can be used as a treatment of amyloidogenesis and neuroinflammation disease such as $\mathrm{AD}$ and disease by NF- $\kappa B$ activation.

\section{Competing interests}

The authors declare that they have no competing interests.

\section{Authors' contributions}

J-TH and D-JS designed the study and prepared the manuscript. S-MG and M-HP performed experiments. C-JH performed animal behavioral tests. H-SS, $\mathrm{S}-\mathrm{BH}, \mathrm{K}-\mathrm{WO}$, and U-SL discussed the study. Y-WH performed the molecular modeling study. M-JS helped to draft the manuscript. All authors have read and approved the final version of this manuscript.

\section{Authors' information}

J-TH and D-JS contributed equally to this paper and are co-corresponding authors.

\section{Acknowledgements}

This work was supported by the National Research Foundation of Korea (NRF) Grant funded by the Korea government (MSIP) (MRC, 2008-0062275).

\section{Author details \\ 'College of Pharmacy and Medical Research Center, Chungbuk National University, 194-31 Osongsaemgmyeong 1-ro, Osong-eup, Heungdeok-gu, Cheongju, Chungbuk 361-951, Republic of Korea. ${ }^{2}$ College of Oriental Medicine, Gachon University, San 65, Bokjeong-dong, Sujeong-gu, Seongnam, Gyeonggii-do 461-701, Republic of Korea. ${ }^{3}$ Department of Food Science \& Technology, Korea National University of Transportation, Jeungpyeong 368-701, Republic of Korea. ${ }^{4}$ Department of Chemistry, Utah Valley University, $800 \mathrm{~W}$ University Pkwy, Orem, UT 84058, USA. ${ }^{5}$ Department of Obstetrics and Gynecology, Daejeon St. Mary's Hospital, College of Medicine, The Catholic University of Korea, 64 Daeheung-roJung gu, Daejeon 301-723, Republic of Korea.}

Received: 9 April 2015 Accepted: 15 June 2015

Published online: 26 June 2015

\section{References}

1. Selkoe DJ. Alzheimer's disease is a synaptic failure. Science. 2002;298:789-91.

2. LaFerla FM, Green KN, Oddo S. Intracellular amyloid-beta in Alzheimer's disease. Nat Rev Neurosci. 2007:8:499-509.

3. Wood AJJMD, Cummings JLMD. Alzheimer's disease. N Engl J Med. 2004;351:56-67.
4. Li X, Buxbaum JN. Transthyretin and the brain re-visited: is neuronal synthesis of transthyretin protective in Alzheimer's disease? Mol Neurodegener. 2011;6:79.

5. Holsinger RM, McLean CA, Beyreuther K, Masters CL, Evin G. Increased expression of the amyloid precursor beta-secretase in Alzheimer's disease. Ann Neurol. 2002:51:783-6.

6. Pascual-Lucas M, Fernandez-Lizarbe S, Montesinos J, Guerri C. LPS or ethanol triggers clathrin- and rafts/caveolae-dependent endocytosis of TLR4 in cortical astrocytes. J Neurochem. 2014;129:448-62.

7. Min KJ, Choi K, Kwon TK. Withaferin A down-regulates lipopolysaccharideinduced cyclooxygenase-2 expression and PGE2 production through the inhibition of STAT1/3 activation in microglial cells. Int Immunopharmacol. 2011;11:1137-42.

8. Miklossy J, Kis A, Radenovic A, Miller L, Forro L, Martins R, et al. Beta-amyloid deposition and Alzheimer's type changes induced by Borrelia spirochetes. Neurobiol Aging. 2006;27:228-36.

9. Lee JW, Lee YK, Yuk DY, Choi DY, Ban SB, Oh KW, et al. Neuro-inflammation induced by lipopolysaccharide causes cognitive impairment through enhancement of beta-amyloid generation. J Neuroinflammation. 2008;5:37

10. DiCarlo G, Wilcock D, Henderson D, Gordon M, Morgan D. Intrahippocampal LPS injections reduce Abeta load in APP+PS1 transgenic mice. Neurobiol Aging. 2001;22:1007-12.

11. Huang SS, Chiu CS, Chen HJ, Hou WC, Sheu MJ, Lin YC, et al. Antinociceptive activities and the mechanisms of anti-inflammation of asiatic acid in mice. Evid Based Complement Alternat Med. 2011;2011:895857.

12. Buggia-Prevot V, Sevalle J, Rossner S, Checler F. NFkappaB-dependent control of BACE1 promoter transactivation by Abeta42. J Biol Chem. 2008;283:10037-47.

13. Chen CH, Zhou W, Liu S, Deng Y, Cai F, Tone M, et al. Increased NF-kappaB signalling up-regulates BACE1 expression and its therapeutic potential in Alzheimer's disease. Int J Neuropsychopharmacol. 2012;15:77-90.

14. Lin GH, Lee YJ, Choi DY, Han SB, Jung JK, Hwang BY, et al. Antiamyloidogenic effect of thiacremonone through anti-inflamation in vitro and in vivo models. J Alzheimers Dis. 2012;29:659-76.

15. Lee JW, Lee YK, Ban JO, Ha TY, Yun YP, Han SB, et al. Green tea (-)-epigallocatechin-3-gallate inhibits beta-amyloid-induced cognitive dysfunction through modification of secretase activity via inhibition of ERK and NF-kappaB pathways in mice. J Nutr. 2009;139:1987-93.

16. Ban JO, Oh JH, Kim TM, Kim DJ, Jeong HS, Han SB, et al. Anti-inflammatory and arthritic effects of thiacremonone, a novel sulfur compound isolated from garlic via inhibition of NF-kappaB. Arthritis Res Ther. 2009;11:R145.

17. Kim EA, Han AR, Choi J, Ahn JY, Choi SY, Cho SW. Anti-inflammatory mechanisms of $\mathrm{N}$-adamantyl-4-methylthiazol-2-amine in lipopolysaccharidestimulated BV-2 microglial cells. Int Immunopharmacol. 2014;22:73-83.

18. Suh SJ, Kim KS, Kim MJ, Chang YC, Lee SD, Kim MS, et al. Effects of bee venom on protease activities and free radical damages in synovial fluid from type II collagen-induced rheumatoid arthritis rats. Toxicol In Vitro. 2006;20:1465-71.

19. Son DJ, Lee JW, Lee YH, Song HS, Lee CK, Hong JT. Therapeutic application of anti-arthritis, pain-releasing, and anti-cancer effects of bee venom and its constituent compounds. Pharmacol Ther. 2007;115:246-70.

20. Chung ES, Kim H, Lee G, Park S, Kim H, Bae H. Neuro-protective effects of bee venom by suppression of neuroinflammatory responses in a mouse model of Parkinson's disease: role of regulatory T cells. Brain Behav Immun. 2012;26:1322-30.

21. Li J, Ke T, He C, Cao W, Wei M, Zhang L, et al. The anti-arthritic effects of synthetic melittin on the complete Freund's adjuvant-induced rheumatoid arthritis model in rats. Am J Chin Med. 2010;38:1039-49.

22. Seo SW, Jung WS, Lee SE, Choi CM, Shin BC, Kim EK, et al. Effects of bee venom on cholecystokinin octapeptide-induced acute pancreatitis in rats. Pancreas. 2008:36:e22-9.

23. Park HJ, Lee SH, Son DJ, Oh KW, Kim KH, Song HS, et al. Antiarthritic effect of bee venom: inhibition of inflammation mediator generation by suppression of NF-kappaB through interaction with the p50 subunit. Arthritis Rheum. 2004:50:3504-15.

24. Wang C, Chen T, Zhang N, Yang M, Li B, Lu X, et al. Melittin, a major component of bee venom, sensitizes human hepatocellular carcinoma cells to tumor necrosis factor-related apoptosis-inducing ligand (TRAIL)-induced apoptosis by activating CaMKII-TAK1-JNK/p38 and inhibiting IkappaBalpha kinase-NFkappaB. J Biol Chem. 2009;284:3804-13. 
25. Park HJ, Lee HJ, Choi MS, Son DJ, Song HS, Song MJ, et al. JNK pathway is involved in the inhibition of inflammatory target gene expression and NF-kappaB activation by melittin. J Inflamm (Lond). 2008;5:7.

26. Lee YJ, Choi DY, Yun YP, Han SB, Kim HM, Lee K, et al. Ethanol extract of Magnolia officinalis prevents lipopolysaccharide-induced memory deficiency via its antineuroinflammatory and antiamyloidogenic effects. Phytother Res. 2013;27:438-47.

27. Morris R. Developments of a water-maze procedure for studying spatial learning in the rat. J Neurosci Methods. 1984;11:47-60.

28. Lee YJ, Choi IS, Park MH, Lee YM, Song JK, Kim YH, et al. 4-O-Methylhonokio attenuates memory impairment in presenilin 2 mutant mice through reduction of oxidative damage and inactivation of astrocytes and the ERK pathway. Free Radic Biol Med. 2011;50:66-77.

29. Trott O, Olson AJ. AutoDock Vina: improving the speed and accuracy of docking with a new scoring function, efficient optimization, and multithreading. J Comput Chem. 2010;31:455-61.

30. Lee YJ, Choi DY, Choi IS, Kim KH, Kim YH, Kim HM, et al. Inhibitory effect of 4-O-methylhonokiol on lipopolysaccharide-induced neuroinflammation, amyloidogenesis and memory impairment via inhibition of nuclear factorkappaB in vitro and in vivo models. J Neuroinflammation. 2012;9:35.

31. Wan Y, Xu J, Meng F, Bao Y, Ge Y, Lobo N, et al. Cognitive decline following major surgery is associated with gliosis, beta-amyloid accumulation, and tau phosphorylation in old mice. Crit Care Med. 2010;38:2190-8.

32. Choi DY, Lee JW, Lin G, Lee YK, Lee YH, Choi IS, et al. Obovatol attenuates LPS-induced memory impairments in mice via inhibition of NF-kappaB signaling pathway. Neurochem Int. 2012;60:68-77.

33. Lee YJ, Choi DY, Yun YP, Han SB, Oh KW, Hong JT. Epigallocatechin-3gallate prevents systemic inflammation-induced memory deficiency and amyloidogenesis via its anti-neuroinflammatory properties. J Nutr Biochem. 2013;24:298-310.

34. Chami L, Buggia-Prevot V, Duplan E, Delprete D, Chami M, Peyron JF, et al. Nuclear factor-kappaB regulates betaAPP and beta- and gamma-secretases differently at physiological and supraphysiological Abeta concentrations. J Biol Chem. 2012;287:24573-84.

35. Huang $X$, Chen $Y$, Zhang $H, M a ~ Q$, Zhang YW, Xu H. Salubrinal attenuates beta-amyloid-induced neuronal death and microglial activation by inhibition of the NF-kappaB pathway. Neurobiol Aging. 2012;33:1007. e1009-1017.

36. Guo JT, Yu J, Grass D, de Beer FC, Kindy MS. Inflammation-dependent cerebral deposition of serum amyloid a protein in a mouse model of amyloidosis. J Neurosci. 2002;22:5900-9.

37. Xiaohua Deng ML, Weiming Al, Lixin HE, Dahua LU, Patrylo PR, Huaibin CAl, et al. Lipopolysaccharide-induced neuroinflammation is associated with Alzheimer-like amyloidogenic axonal pathology and dendritic degeneration in rats. Advances in Alzheimer's Dis. 2014;3:78-93.

38. Glass CK, Saijo K, Winner B, Marchetto MC, Gage FH. Mechanisms underlying inflammation in neurodegeneration. Cell. 2010;140:918-34.

39. Wyss-Coray T. Inflammation in Alzheimer disease: driving force, bystander or beneficial response? Nat Med. 2006;12:1005-15.

40. Hauss-Wegrzyniak B, Dobrzanski P, Stoehr JD, Wenk GL. Chronic neuroinflammation in rats reproduces components of the neurobiology of Alzheimer's disease. Brain Res. 1998;780:294-303.

41. Fan $L$, Wang $T$, Chang $L$, Song $Y$, Wu $Y$, Ma D. Systemic inflammation induces a profound long term brain cell injury in rats. Acta Neurobiol Exp (Wars). 2014;74:298-306.

42. Lee YJ, Choi DY, Choi IS, Han JY, Jeong HS, Han SB, et al. Inhibitory effect of a tyrosine-fructose Maillard reaction product, 2,4-bis(p-hydroxyphenyl)-2-butenal on amyloid-beta generation and inflammatory reactions via inhibition of NF-kappaB and STAT3 activation in cultured astrocytes and microglial BV-2 cells. J Neuroinflammation. 2011;8:132.

43. Haass C, Hung AY, Selkoe DJ. Processing of beta-amyloid precursor protein in microglia and astrocytes favors an internal localization over constitutive secretion. J Neurosci. 1991;11:3783-93.

44. O'Neill LA, Kaltschmidt C. NF-kappa B: a crucial transcription factor for glial and neuronal cell function. Trends Neurosci. 1997;20:252-8.

45. Rolova T, Puli L, Magga J, Dhungana H, Kanninen K, Wojciehowski S, et al. Complex regulation of acute and chronic neuroinflammatory responses in mouse models deficient for nuclear factor kappa B p50 subunit. Neurobiol Dis. 2014;64:16-29.

46. Bae MK, Kim SR, Lee HJ, Wee HJ, Yoo MA, Ock Oh S, et al. Aspirin-induced blockade of NF-kappaB activity restrains up-regulation of glial fibrillary acidic protein in human astroglial cells. Biochim Biophys Acta. 1763;2006:282-9.
47. Webster CM, Hokari M, McManus A, Tang XN, Ma H, Kacimi R, et al. Microglial P2Y12 deficiency/inhibition protects against brain ischemia. PLoS One. 2013;8, e70927.

48. Wang HM, Zhang T, Huang JK, Sun XJ. 3-N-butylphthalide (NBP) attenuates the amyloid-beta-induced inflammatory responses in cultured astrocytes via the nuclear factor-kappaB signaling pathway. Cell Physiol Biochem. 2013;32:235-42

49. Peng Y, Sun J, Hon S, Nylander AN, Xia W, Feng Y, et al. L-3-n-butylphthalide improves cognitive impairment and reduces amyloid-beta in a transgenic model of Alzheimer's disease. J Neurosci. 2010;30:8180-9.

50. Kim JA, Yun HM, Jin P, Lee HP, Han JY, Udumula V, et al. Inhibitory effect of a 2,4-bis(4-hydroxyphenyl)-2-butenal diacetate on neuro-inflammatory reactions via inhibition of STAT1 and STAT3 activation in cultured astrocytes and microglial BV-2 cells. Neuropharmacology. 2014;79:476-87.

51. Lee SY, Son DJ, Lee YK, Lee JW, Lee HJ, Yun YW, et al. Inhibitory effect of sesaminol glucosides on lipopolysaccharide-induced NF-kappaB activation and target gene expression in cultured rat astrocytes. Neurosci Res. 2006:56:204-12.

52. Sharma RK, Pande V, Ramos MJ, Rajor HK, Chopra S, Meguro K, et al. Inhibitory activity of polyhydroxycarboxylate chelators against recombinant NF-kappaB p50 protein-DNA binding. Bioorg Chem. 2005;33:67-81.

53. Lin YZ, Yao SY, Veach RA, Torgerson TR, Hawiger J. Inhibition of nuclear translocation of transcription factor NF-kappa B by a synthetic peptide containing a cell membrane-permeable motif and nuclear localization sequence. J Biol Chem. 1995;270:14255-8.

54. Yang EJ, Jiang JH, Lee SM, Yang SC, Hwang HS, Lee MS, et al. Bee venom attenuates neuroinflammatory events and extends survival in amyotrophic lateral sclerosis models. J Neuroinflammation. 2010;7:69.

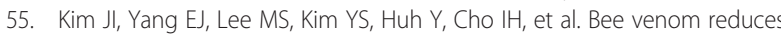
neuroinflammation in the MPTP-induced model of Parkinson's disease. Int J Neurosci. 2011;121:209-17.

56. Choi KE, Hwang CJ, Gu SM, Park MH, Kim JH, Park JH, et al. Cancer cell growth inhibitory effect of bee venom via increase of death receptor 3 expression and inactivation of NF-kappa B in NSCLC cells. Toxins (Basel). 2014;6:2210-28.

57. Park MH, Choi MS, Kwak DH, Oh KW. Yoon do Y, Han SB, et al. Anti-cancer effect of bee venom in prostate cancer cells through activation of caspase pathway via inactivation of NF-kappaB. Prostate. 2011;71:801-12.

58. Son DJ, Ha SJ, Song HS, Lim Y, Yun YP, Lee JW, et al. Melittin inhibits vascular smooth muscle cell proliferation through induction of apoptosis via suppression of nuclear factor-kappaB and Akt activation and enhancement of apoptotic protein expression. J Pharmacol Exp Ther. 2006;317:627-34.

\section{Submit your next manuscript to BioMed Central and take full advantage of:}

- Convenient online submission

- Thorough peer review

- No space constraints or color figure charges

- Immediate publication on acceptance

- Inclusion in PubMed, CAS, Scopus and Google Scholar

- Research which is freely available for redistribution

Submit your manuscript at www.biomedcentral.com/submit 